\title{
Безгражданство в Российской Федерации
}

Тарасьяни Е.В.*

Рассматриваются различные аспекты проблемы безгражданства в Российской Федерации. Речь идет об истории развития законодательства о лицах без гражданства, современном статусе лиц без гражданства в России. Кроме того, кратко излагаются причины безгражданства и даются рекомендации по исправлению ситуации.

Ключевые слова: лицо без гражданства; безгражданство; гражданство.

Понятие безгражданства в России появилось недавно - в советский период. В законодательных актах первоначально вообще не употреблялся этот термин, не признавалось наличие такой категории лиц, как лица без гражданства, не производился их учет.

Само понятие гражданства, а точнее подданства, окончательно сложилось в имперский период. Изучение нормативных материалов этой эпохи, а также доктрины ${ }^{1}$, которая дает толкование данным актам, показывает, что в это время не существовало понятия «лицо без гражданства». Так, в Своде законов Российской империи упоминаются такие категории («состояния») населения, как подданные, инородцы (неславянские русские подданные, в частности монгольские, тюркские и финские племена, стоящие на низкой ступени культуры (ст. 762 Свода законов Российской империи²)).

Таким образом, в Российской империи лиц без гражданства не существовало, поскольку все лица, не имевшие иностранного подданства или гражданства, считались подданными Российской империи. В доктрине того времени встречается мнение, что бесподданство вообще невозможно, а сам бесподданный не может считаться иностранцем: статус иностранца характеризуется совокупностью международноправовых обязанностей, ограничивающих господство над ним терри-

\footnotetext{
* Тарасьянц Елена Валерьевна - аспирант кафедры международного права МГИМО (У) МИД России yelenavt@rambler.ru.

${ }^{1}$ См., например, Коркунов Н.М. Русское государственное право. Т. 1. Введение и Общая часть / Ред. М.Б. Горенберг. 6-е изд. СПб., 1909. URL: http:/civil.consultant.ru/reprint/ books/97/ (дата обращения: 09.11.2009).

2 Свод законов Российской империи. T. IX. URL: http://civil.consultant.ru/reprint/ books/205/87.html\#img88 (дата обращения: 09.11.2009).
} 
ториальной власти; этих обязанностей по отношению к бесподданному территориальная власть не несет, и ничто не препятствует уравниванию его в правах и обязанностях с подданными. Совершенно ясно в таких условиях, что бесподданный не является иностранцем. Бесподданный рассматривается как подданный того государства, с которым он связан совокупностью фактических отношений ${ }^{3}$.

В начале советского периода такой категории населения, как лица без гражданства, также не существовало. Положения о гражданстве $20-\mathrm{X}-30-\mathrm{x}$ гг. XX в. закрепляли презумпцию принадлежности к гражданству СССР лица, которое находится на территории СССР и не может доказать свою принадлежность к гражданству другого государства. Так, согласно ст. 3 Положения о союзном гражданстве 1924 г. каждое лицо, находившееся на территории СССР, признавалось гражданином Союза ССР, поскольку не будет им доказано, что оно является иностранным гражданином ${ }^{4}$.

Впервые понятие «лицо без гражданства» было введено в советское законодательство Законом о гражданстве СССР 1938 г. ${ }^{5}$. Статья 8 Закона предусматривала, что лица, проживающие на территории СССР, не являющиеся в силу этого Закона гражданами СССР и не имеющие доказательств своей принадлежности к иностранному гражданству, считаются лицами без гражданства.

Еще до принятия следующего закона о гражданстве предпринимались попытки сокращения безгражданства. Например, в соответствии со ст. 3 Указа Президиума Верховного Совета СССР от 7 сентября 1940 г. «О порядке приобретения гражданства СССР гражданами Литовской, Латвийской и Эстонской ССР» 6 лица без гражданства, принадлежащие к национальным меньшинствам, которые в условиях политических режимов, существовавших в Литве, Латвии и Эстонии до установления в них советской власти, не могли приобрести литовского, латвийского и эстонского гражданства, приобретали гражданство

3 Гессен В.М. Подданство, его установление и прекращение. Т. 1. С.-Пб.: Тип. «Правда», 1909. С. 136,152

${ }^{4} \mathrm{O}$ союзном гражданстве: Положение, утверждено постановлением ЦИК СССР от 29.10.1924 // С3 СССР.1924. № 23. С. 202.

5 О гражданстве СССР: Закон СССР от 19.08.1938 // Ведомости Верховного Совета CCCP. 1938. № 11.

${ }^{6} \mathrm{O}$ порядке приобретения гражданства СССР гражданами Литовской, Латвийской и Эстонской ССР: Указ Президиума Верховного Совета СССР от 07.09.1940 // Ведомости Верховного Совета СССР. 1940. № 31. 
СССР в порядке, предусмотренном Указом. Остальные лица без гражданства, постоянно проживающие на территории Литовской, Латвийской и Эстонской Советских Социалистических Республик, могли приобрести гражданство СССР на общих основаниях в соответствии со ст. 3 Закона «О гражданстве Союза Советских Социалистических Республик» 1938 г.

В 50-х гг. также были приняты некоторые меры по сокращению безгражданства. В Постановлении Президиума Верховного Совета СССР от 16 декабря 1954 г. «О лицах, длительное время проживающих на территории СССР и не оформивших советского гражданства» указывалось, что в связи с тем, что некоторые лица, которые длительное время проживали в СССР и в соответствии с действовавшим ранее законодательством считались советскими гражданами, а после издания Закона о гражданстве СССР 1938 г. стали рассматриваться как лица без гражданства, Президиум Верховного Совета СССР постановил, что лица, родившиеся за границей и в разное время прибывшие на территорию СССР (за исключением политэмигрантов), проживавшие в Советском Союзе ко времени издания Закона о гражданстве СССР 1938 г. и не представившие документов о своей принадлежности к иностранному гражданству (подданству), а равно их дети являются гражданами СССР. Таким лицам полагалось выдавать советские паспорта, а тем из них, которым были выданы виды на жительство как лицам без гражданства, заменять советскими паспортами ${ }^{7}$.

Поскольку Закон 1938 г. не регулировал всех возникавших в практике вопросов гражданства, было принято решение разработать новый. В новом законе воспроизводились соответствующие положения Конституции СССР 1977 г., были учтены оправдавшие себя на практике положения действовавшего ранее законодательства о гражданстве, а также сложившаяся практика в этой области ${ }^{8}$. Закон о гражданстве СССР 1978 г. отразил понятие «лицо без гражданства» в ст. $9^{9}$ в той же формулировке, что и Закон 1938 г. Помимо определения категории лиц без гражданства, Закон содержал ряд положений, направленных на сокращение безгражданства, в частности безгражданства

7 Цит.по: Кутафин О.Е. Российское гражданство // Доступ из справ.-прав. сис. Консультант-плюс. С. 209

8 Гончаров И.А. Основные этапы развития законодательства о гражданстве в России // Современное право. 2006. № 7. С. 38-39.

9 О гражданстве СССР: Закон СССР от 01.12.1978 № 8497-IX // Ведомости Верховного Совета СССР. 1978. № 49. С. 816. 
детей. С этой целью в ст. 4 Закона были включены положения о сохранении гражданства при заключении и расторжении брака граждан СССР с лицами без гражданства. Приобретение или утрата гражданства СССР одним из супругов не влекло изменения гражданства другого супруга.

В 1981 г. статус лиц без гражданства был в принципе юридически уравнен со статусом иностранцев с принятием Закона о правовом положении иностранных граждан в $\mathrm{CCCP}^{10}$. В частности, ст. 32 Закона предусматривала, что его положения распространяются на лиц без гражданства в СССР, если иное не вытекает из законодательства СССР. Этот Закон действовал вплоть до 2002 г.

Принятый в 1990 г. очередной Закон о гражданстве СССР 11 предусматривал ряд положений, схожих с положениями своего предшественника - Закона 1978 г. Так, он содержал аналогичное определение понятия «лицо без гражданства» (ст. 12), ст. 7 о сохранении гражданства при заключении и расторжении брака, положения о гражданстве детей, один из родителей которых является гражданином СССР (ст. 15), которая была дополнена нормой о том, что в случае установления отцовства ребенка, мать которого является лицом без гражданства, а отцом признается гражданин СССР, ребенок, не достигший 14 лет, становится гражданином СССР независимо от места рождения); ст. 16 о приобретении гражданства СССР детьми без гражданства; ст. 17 о гражданстве детей, родители которых неизвестны; ст. 18 о приеме в гражданство СССР на недискриминационной основе, дополненную основаниями отклонения ходатайства о приеме в гражданство СССР; ст. 26 о приобретении детьми гражданства СССР в случае приобретения гражданства СССР одним из родителей; ст. 28 о приобретении детьми гражданства СССР в случае усыновления; ст. 29 о сохранении детьми гражданства СССР в случае усыновления; ст. 19 о восстановлении в гражданстве. Кроме того, в данном Законе также присутствовала норма о лишении гражданства СССР в измененной формулировке (ст. 23). И, так же как и в Законе 1978 г,, отсутствие у лица иного гражданства и гарантий его приобретения не рассматривалось в качестве основания запрета выхода из гражданства.

${ }^{10}$ О правовом положении иностранных граждан в СССР: Закон от 24.06.1981 № 5152Х // Ведомости ВС СССР. 1981. № 26. С. 836.

11 О гражданстве СССР: Закон от 23.05.1990 // Ведомости СНД и ВС СССР.1990. № 23. C. 435. 
Следующим шагом на пути правового регулирования статуса лиц без гражданства стал Закон «О гражданстве РСФСР» 1991 г. ${ }^{12}$. Закон значительно отличается от своих предшественников. В Законе дается определение лица без гражданства, отличное от содержавшегося в предыдущих законах. В частности, из определения исключен критерий необходимости проживания на территории страны (ст. 11, п. в)). В Законе также предусмотрен ряд мер, направленных на сокращение безгражданства. В соответствии со ст. 15 , если один из родителей ребенка на момент его рождения состоит в гражданстве РСФСР, а другой является лицом без гражданства, ребенок является гражданином РСФСР независимо от места рождения. При различном гражданстве родителей, один из которых на момент рождения ребенка состоит в гражданстве РСФСР, а другой имеет иное гражданство, вопрос о гражданстве ребенка независимо от места его рождения определяется письменным соглашением родителей. При отсутствии такого соглашения ребенок приобретает гражданство РФ, если он родился на территории РФ либо если иначе он стал бы лицом без гражданства.

В 2002 г. были приняты современные законы о гражданстве ${ }^{13}$ и правовом положении иностранных граждан ${ }^{14}$. Однако некоторые из ранее принятых актов продолжают ограниченно применяться. Например, Закон о гражданстве 1991 г.

Вышеизложенные факты позволяют сделать вывод о том, что проблема безгражданства появилась в России сравнительно недавно - в советский период, поскольку ранее лицо, гражданство которого не определено, рассматривалось в качестве подданного (гражданина) России, если находилось на его территории. Регламентацию вопросов безгражданства в советский период нельзя назвать полной и четкой. В течение данного периода времени происходило развитие норм в сторону их уточнения: изменялись определение понятия «лицо без гражданства» и критерии отнесения лица к данной категории населения страны; изменялось регулирование вопросов лишения и утраты гражданства; предпринимались попытки сократить безгражданство. В конечном итоге во многом в результате принятых международных обязательств 12 О гражданстве РСФСР: Закон от 28.11.1991 № 1948-1 // Ведомости СНД и ВС РФ. 1992. № 6. С. 243.

13 О гражданстве РФ: ФЗ от 31.05.2002 № 62-Ф3 // Собрание законодательства РФ. 2002. № 22. С. 2031.

14 О правовом положении иностранных граждан в РФ: ФЗ от 25.07.2002 № 115-Ф3 // Собрание законодательства РФ. 2002. № 30. С.3032. 
происходила постепенная демократизация законодательства о гражданстве в целом.

Проблемы с получением российского гражданства возникали и возникают у многих групп населения: турков-месхетинцев, курдов, езидов, батумских курманчей, хемшилов, бакинских армян, грузин из Абхазии, афганцев, бывших соотечественников. Большинству из них гражданство может быть предоставлено на законных основаниях. В частности, многие лица без гражданства из этих групп на самом деле стали гражданами России по признанию. Осложняют ситуацию дискриминационные действия властей.

Кроме того, ситуация некоторых категорий населения осложняется событиями, происходящими на международной арене. В качестве примера можно привести положение беженцев из Абхазии. По сообщениям неправительственных организаций, за 16 лет жизни в России положение беженцев из Абхазии постоянно и неуклонно ухудшалось. 1 октября 2009 г. этот процесс завершился делегализацией последней группы абхазских беженцев ${ }^{15}$. Однако следует также напомнить, что российско-грузинская война 2008 г. и признание Россией независимости Абхазии, не обусловленное обязательством создать условия для возвращения беженцев, лишило их последних надежд вернуться на родину. В то же время это способствовало закреплению стереотипа враждебности по отношению к грузинам, который начал складываться в обществе, и особенно в сознании бюрократии. В результате, например, получить разрешение на временное проживание в счет квоты для грузин стало практически невозможно ${ }^{16}$.

Все же были предложены и возможные выходы из создавшегося положения. В качестве примера можно назвать решение начальника Управления Федеральной миграционной службы (УФМС) по Краснодарскому краю В.А. Карасева, который на заседании Общественного Совета при УФМС заявил, что его ведомство намерено решить вопрос о гражданстве отдельных групп национальных меньшинств, проживающих на территории Краснодарского края (турки-месхетинцы, курды, езиды

15 Российско-абхазские сюжеты: абхазские беженцы теряют в России легальный статус, а российские граждане в Абхазии - жилье // Комитет «Гражданское содействие», 14 октября 2009 г.. URL: http://refugee.ru/news/2009-10-14-26 (дата обращения: 09.11.2009) 16 Положение беженцев из Абхазии в Российской Федерации. По опыту работы Комитета «Гражданское содействие» и московского пункта сети «Миграция и Право». URL: http://refugee.ru/publ/dokumenty/polozhenie_bezhencev_iz_abkhazii_v_rossijskoj_ federacii/9-1-0-9 (дата обращения: 09.11.2009). 
и т.д.) и выдачи им российских паспортов до конца 2007-го или в первом квартале 2008 г. Лиц, которым предполагалось выдать паспорта, насчитывалось около тысячи человек, из которых около 400 - турки-месхетинцы. Работа велась по согласованию с администрацией края и ФМС РФ ${ }^{17}$. Однако никаких данных об успешных результатах в этой области пока нет. Еще одной мерой по улучшению положения лиц без гражданства является Программа по переселению бывших соотечественников.

Анализ положения вышеназванных категорий лиц, проживающих в РФ, показывает, что существуют следующие причины безгражданства в РФ, общие в принципе для всех рассмотренных категорий.

Во-первых, основная проблема изначально связана с признанием наличия гражданства РФ у данных категорий лиц. Часть 7 ст. 4 Ф3 «О гражданстве РФ» 2002 г. предусматривает, что наличие у лица гражданства РФ либо факт наличия у лица в прошлом гражданства СССР определяется на основании законодательных актов РФ, РСФСР или СССР, международных договоров РФ, РСФСР или СССР, действовавших на день наступления обстоятельств, с которыми связывается наличие у лица соответствующего гражданства. Лица, проживавшие в России на 6 февраля 1992 г., на дату вступления в силу Закона «О гражданстве» 1991 г., должны считаться гражданами РФ по признанию, они не отказывались от российского гражданства ${ }^{18}$. Однако на практике они продолжают сохранять статус лиц без гражданства. Гражданство лиц, проживающих в России, определялось государственными органами исходя из наличия регистрации по месту жительства. Но не у всех такая регистрация была; кроме того, все попытки зарегистрироваться зачастую были безуспешными. Такие же сложности испытывают лица, пытающиеся подтвердить свое постоянное проживание в РФ на 1 января 2002 г., чтобы воспользоваться упрощенной процедурой приема в гражданство (ст. 14 Ф3 «О гражданстве РФ»).

Во-вторых, существует проблема с подтверждением факта постоянного проживания в России. Хотя практикой высших судов была подтверждена возможность установления факта постоянного проживания

17 Положение этнических меньшинств и проявление нетерпимости в Краснодарском крае, Обзор за 1-30 ноября 2007 г. // Правозащитный Центр «Мемориал», www.memo. $\mathrm{ru} / \mathrm{hr} / \mathrm{discrim} / \mathrm{ver1}$ /index.htm (дата обращения: 09.11.2009).

18 Согласно ч. 1 ст. 13 Закона «О гражданстве» 1991 г. гражданами РСФСР признавались все граждане бывшего СССР, постоянно проживающие на территории РСФСР на день вступления в силу этого Закона (6 февраля 1992 г.), если в течение одного года после этого дня они не заявят о своем нежелании состоять в гражданстве РСФСР. 
в РФ решением суда, не во всех местах такой порядок признается. Во многих случаях миграционные органы требуют наличия регистрации как подтверждения такого факта.

В-третьих, существуют определенные сложности с получением гражданства РФ детьми, родители которых являются лицами без гражданства. Если в Законе 1991 г. предусматривалось, что дети, родившиеся от лиц без гражданства на российской территории, являются российскими гражданами (ч. 2 ст. 17), то п. в) ч. 1 ст. 12 Ф3 «О гражданстве РФ» 2002 г. гласит, что ребенок, родители (или один из родителей) которого являются лицами без гражданства, приобретает гражданство РФ по рождению, если родители проживают на территории РФ и ребенок родился на территории РФ. Таким образом, Закон 2002 г. содержит более жесткие правила: если раньше для получения гражданства РФ ребенком, родители которого являются лицами без гражданства, было достаточно, чтобы он был рожден на территории РФ, то теперь требуется, чтобы родители проживали в России. Причем проживать они должны законно, т.е. они должны быть надлежащим образом зарегистрированными по месту жительства.

К этой проблеме прибавляются также злоупотребления государственных органов, оформляющих гражданство детям. Так, в одном из докладов правозащитной организации отмечается следующее. В некоторых регионах, например в Московской и Кировской областях, работники паспортно-визовых служб совершенно необоснованно предлагают родителям-мигрантам, приехавшим в РФ вместе с детьми, сначала получить гражданство самим, а затем оформлять гражданство детям. При этом детям предлагается вначале оформить вид на жительство.

Самые большие трудности в приобретении гражданства возникают у тех, кто прибыл в РФ в детском возрасте, находился или продолжает находиться на попечении родственников и не имеет документов, удостоверяющих личность. Выросшие дети попадают в безвыходную ситуацию, они фактически лишены всех прав и не могут даже выехать в страну исхода для решения своих проблем, поскольку у них нет никакого идентифицирующего личность документа.

Участились случаи обращений граждан, связанные с возвратом заявлений о приеме в гражданство детей в связи с выявлением необоснованности документирования одного из родителей паспортом гражданина РФ ${ }^{19}$.

19 Ганнушкина С.А. Доклад о положении беженцев, внутриперемещенных лиц и вынужденных переселенцев в России. 2007. URL: www.refugee.ru/refugees/situatdec.htm 
Кроме того, были выявлены отказы в выдаче вкладышей в свидетельство о рождении, подтверждающих гражданство РФ ребенка 20 . Данная ситуация является результатом попустительства государственных органов. Нужно также заметить, что необходимо обращать внимание на дату рождения ребенка. В зависимости от этой даты будет применяться для определения гражданства ребенка либо Закон 1991 г. (если ребенок родился после вступления в силу Закона 1991 г., но до вступления в силу Закона 2002 г.), либо Закон 2002 г.

В-четвертых, в стране действует сложная процедура получения гражданства, в частности в части получения разрешения на временное проживание и вида на жительство, включая квотирование выдачи разрешений на временное проживание. До последнего времени действовало письмо заместителя директора ФМС России Леденева, согласно которому люди, установившие в судебном порядке свое постоянное проживание с 2002 г., могли подать документы на разрешение на временное проживание, во-первых, без предъявления миграционной карты, а во-вторых, без справки о судимости в той стране, где они жили когда-то. После изменения законодательства в январе 2007 г. во многих регионах это положение миграционные власти ставят под сомнение 21 .

В-пятых, многие лица без гражданства не в состоянии собрать все необходимые документы для оформления гражданства РФ. У них не хватает средств, для того чтобы выехать за пределы своего места проживания в РФ для оформления необходимых документов. Многие утратили связь со страной исхода.

В-шестых, еще одну проблему составляет легализация лиц, отбывших наказание за совершенное ими преступление. Если до заключения они не приобрели гражданства РФ, то их легализация оказывается невозможной по причине наличия непогашенной судимости. При

(дата обращения: 16.11.2009).

20 Доклад от 22.03.2006 г. о деятельности Уполномоченного по правам ребенка в г. Москве, о соблюдении и защите прав, свобод и законных интересов ребенка в 2005 г. // Доступ из справ.-прав. системы Консультант-плюс. С. 39-40

21 Лица без гражданства в Российской Федерации. Ликвидация безгражданства и соблюдение прав ЛБГ // Материалы предоставлены С. Ганнушкиной, председателем Комитета «Гражданское содействие». С. 3-4; Бобров Е.А. Проблемы правового положения иностранных граждан и лиц без гражданства из числа бывших граждан CCCP, желающих остаться на постоянное проживание в Российской Федерации // Приобретение гражданства РФ и легализация иностранных граждан в России. Материалы 18-го семинара, проведенного в рамках программы «Миграция и право» Правозащитного центра «Мемориал» 28-30 октября 2004 г. М.: Р. Валент, 2005. С. 80-82. 
этом большинство из них утратило всякую связь с той республикой, где они когда-то были прописаны. Не вызывает сомнения, что такое положение опасно не только для самих освободившихся, но и для общества, поскольку ставит их вне закона и толкает на совершение новых преступлений 22 .

В-седьмых, большую проблему составляет проходящая повсеместно проверка законности выдачи и изъятие российских паспортов. Этой проблеме был посвящен доклад Уполномоченного по правам человека ${ }^{23}$, на эту проблему обращали внимания правозащитные организации ${ }^{24}$. По сообщению Уполномоченного по правам человека, в некоторых регионах в случае, если необоснованная выдача паспорта произошла по вине сотрудников паспортно-визовой службы, сама эта служба оказывает пострадавшим содействие в оформлении документов для приобретения российского гражданства. Провинившиеся сотрудники наказываются в единичных случаях. Лицам, у которых изъят паспорт, предлагается оформить вид на жительство в РФ в качестве лица без гражданства с последующим приобретением российского гражданства либо восстановлением паспорта страны исхода.

Возникновению многочисленных ошибок при определении принадлежности к гражданству Российской Федерации способствует то, что проверка наличия российского гражданства у заявителей, имевших в прошлом гражданство СССР и проживавших за пределами РФ, проводится органами ФМС России по сформированной Консульским департаментом МИД России базе данных о лицах, приобретших гражданство РФ через дипломатические представительства и консульские учреждения РФ в государствах СНГ. После передачи указанной базы данных в органы паспортно-визовой службы МВД России, а впоследствии в ФМС России подразделениями последней была фактически прекращена практика направления запросов о подтверждении российского

22 Лица без гражданства в Российской Федерации. Ликвидация безгражданства и соблюдение прав ЛБГ // Материалы предоставлены С. Ганнушкиной, председателем Комитета «Гражданское содействие». С. 5.

${ }^{23}$ О практике изъятия российских паспортов у бывших граждан СССР, переселившихся в РФ из стран СНГ. Специальный доклад Уполномоченного по правам человека в РФ. M., 2007. URL: http://www.ombudsman.gov.ru/doc/spdoc/0207.shtml (дата обращения: 16.11.2009)

24 Лица без гражданства в Российской Федерации. Ликвидация безгражданства и соблюдение прав ЛБГ // Материалы предоставлены С. Ганнушкиной, председателем Комитета »Гражданское содействие«. С. 4-5. 
гражданства в Консульский департамент МИД России и в загранпредставительства по месту приобретения соотечественниками российского гражданства.

Между тем Консульский департамент МИД России неоднократно указывал на неполноту сведений, содержащихся в указанной базе данных, рекомендуя не выносить заключение об отсутствии у проверяемого лица гражданства Российской Федерации без дополнительной проверки по иным источникам ${ }^{25}$.

Проведенное исследование позволяет сделать следующие выводы.

Во-первых, история развития российского права и государства показывает, какое влияние оказывала на формирование норм о гражданстве политическая обстановка. Такие события, как депортация ряда народностей советскими властями или распад СССР, во многом определили современное положение определенной части населения. Несмотря на то что на сегодняшний день Россия считается демократическим государством, здесь все еще имеет место дискриминация и некомпетентность государственных органов, которые оказываются неспособными решить стоящие перед ними задачи.

Во-вторых, основными группами, которые имеют статус лиц без гражданства, на сегодняшний день являются: турки-месхетинцы (поскольку не всем из них удалось помочь при проведении программы переселения в США), курды, батумские курманчи, езиды, хемшилы, бакинские армяне, грузины из Абхазии и беженцы из Афганистана. Большую группу лиц без гражданства составляют бывшие граждане CССР, которые приехали на территорию России до 2002 г. и с принятием нового законодательства утратили статус законно проживающего в России населения.

В-третьих, основной причиной безгражданства является прежде всего проблема признания гражданства РФ за теми лицами, кто проживал в России на 6 февраля 1992 г. - дату вступления в силу Закона «О гражданстве» 1991г. Многие люди из вышеназванных категорий населения столкнулись именно с этой проблемой, когда пытались получить российское гражданство. А ведь они должны считаться гражданами РФ по признанию.

25 О практике изъятия российских паспортов у бывших граждан СССР, переселившихся в РФ из стран СНГ. Специальный доклад Уполномоченного по правам человека в РФ. М., 2007. URL: http://ombudsman.gov.ru/doc/ezdoc/07.shtml (дата обращения: 16.11.2009). 
Вообще, чтобы получить российское гражданство, необходимо подтвердить, что лицо постоянно проживало в РФ в течение определенного времени или на определенную дату. Государственные органы в большинстве случаев придерживаются позиции, согласно которой доказательством данного факта служит наличие регистрации по месту жительства. Хотя судами многократно такая позиция опровергалась, подобная практика все еще сохраняется в ряде мест. Такая практика препятствует получению российского гражданства.

Большое беспокойство вызывает безгражданство детей, поскольку существует практика, когда, в случае если родители являются лицами без гражданства, им предлагается сначала самим оформить гражданство и только после этого - детям. Государственные органы часто неправильно применяют законодательство. Необходимо иметь в виду, что при определении гражданства детей, родившихся после 6 февраля 1991 г. и до вступления в силу Ф3 «О гражданстве РФ» 2002 г., необходимо руководствоваться Законом 1991 г., который, в частности, предусматривает, что дети, рожденные от лиц без гражданства, считаются российскими гражданами, если родились в России.

Не способствует сокращению безгражданства и административная практика государственных органов. Выявляется большое количество злоупотреблений со стороны властей. В недавнее время особенно участились случаи изъятия паспортов по причине отсутствия информации о том, что лицо состоит в гражданстве РФ. При этом таким лицам предлагается оформлять вид на жительство как лицам без гражданства. В такой ситуации повинны сами миграционные органы, поскольку недостаточно тщательно проверяют информацию о наличии гражданства.

В-четвертых, изучение законодательной базы и практики ее применения показывает, что лица без гражданства не получают в России должной помощи и защиты и, кроме того, подвергаются дискриминации. В законодательстве декларируется стремление РФ сокращать безгражданство. Однако на практике возникла ситуация, когда лица без гражданства не могут получить российское гражданство, хотя имеют на это право.

В-пятых, законодательство содержит неполный список документов, удостоверяющих личность лица без гражданства. Практика показывает, что необходим специальный документ, удостоверяющий личность таких лиц. 
В-шестых, исследование показало, что нет общедоступных данных о количестве лиц без гражданства в РФ.

\section{В связи с вышеизложенным представляется необходимым пред-} принять следующее.

Во-первых, необходимо определить, в каком порядке должны получать гражданство все категории лиц без гражданства. Представляется, что те из них, кто проживал в России на момент вступления в силу Закона 1991 г., должны быть признаны российскими гражданами. Что касается возможности переселения ряда народностей в третью страну, то такие меры не решат проблему гражданства всех лиц, являющихся лицами без гражданства.

Во-вторых, необходимо внести в законодательство о гражданстве поправки, касающиеся возможности подтверждения постоянного проживания в России иными способами помимо регистрации по месту жительства.

В-третьих, необходимо внести поправки в законодательство об административных правонарушениях, в частности касающиеся определения срока содержания лиц без гражданства и иностранцев в специальных помещениях при административном выдворении. Кроме того, представляется целесообразным ввести единую административную меру в виде административного выдворения, исключив депортацию.

В-четвертых, необходимо ввести специальный документ - удостоверение личности лица без гражданства.

\section{Библиографический список}

Азаров А. Права человека: международные и российские механизмы защиты/А.Азаров, В.Ройтер, Хюфнер. - М.: Московская школа прав человека, 2003.

Бобров Е.А. Проблемы правового положения иностранных граждан и лиц без гражданства из числа бывших граждан СССР, желающих остаться на постоянное проживание в Российской Федерации // Приобретение гражданства РФ и легализация иностранных граждан в России. Материалы 18-го семинара, проведенного в рамках программы «Миграция и право» Правозащитного центра «Мемориал» 28-30 октября 2004 года. М.: Р. Валент, 2005. С. 80-86.

Ганнушкина С.А. Доклад о положении беженцев, внутриперемещенных лиц и вынужденных переселенцев в России. 2007. URL: www. refugee.ru/refugees/situatdec.htm (дата обращения: 16.11.2009). 
Гессен В.М. Подданство, его установление и прекращение. Т. 1. С.Пб.: Тип. «Правда», 1909. 458 с.

Гончаров И.А. Основные этапы развития законодательства о гражданстве в России//Современное право. 2006. № 7. С. 36 - 40.

Коркунов Н.М. Русское государственное право. Т.1. Введение и Общая часть / Ред. М.Б. Горенберг. 6-е изд. СПб., 1909. URL: http://civil. consultant.ru/reprint/books/97/ (дата обращения: 09.11.2009).

Кутафин О.Е. Российское гражданство//Доступ из справ.-прав. сис. Консультант-плюс.

Лица без гражданства в Российской Федерации. Ликвидация безгражданства и соблюдение прав ЛБГ // Материалы предоставлены С. Ганнушкиной - председателем Комитета «Гражданское содействие».

\section{Statelessness in Russian Federation (Summary)}

\section{Elena V. Tarasyants*}

This article considers various aspects of statelessness in Russian Federation. In particular, it covers the history of legislation regarding stateless persons, actual status of stateless persons in Russia. Furthermore the article concisely describes the reasons of statelessness and recommendations to remedy the situation.

Keywords: stateless person; statelessness; nationality.

\footnotetext{
* Elena V. Tarasyants - post-graduate student of the Chair of International Law, MGIMOUniversity MFA Russia yelenavt@rambler.ru.
} 